\title{
O JULGAMENTO ANTECIPADO PARCIAL DO MÉRITO EO SEU CUMPRIMENTO PROVISÓRIO NO NOVO CPC: APLICAÇÃO SUBSIDIÁRIA AO DIREITO PROCESSUAL DO TRABALHO
}

\author{
THE SUMMARY JUDGMENT ON MERITAND \\ ITSINTERIM INJUNCTIONIN THE NEW CODE OF \\ CIVIL PROCEDURE: SUBSIDIARY APPLICATION OF \\ THE PROCEDURAL LABOR LAW
}

Aline Carneiro Magalhães ${ }^{1}$
Vitor Salino de Moura Eça

1 Doutoranda em Direito pela Pontifícia Universidade Católica de Minas Gerais. Mestrado e graduação em Direito pela Pontifícia Universidade Católica de Minas Gerais. Professora do Ensino Superior. Advogada. E-mail: alinecmagalhaes@gmail.com

2 Prof. Permanente PPGD - PUC-Minas. Pós-doutor UCLM-Espanha. Doutor pela PUC-Minas. Mestre e Especialista. Área. Direito Processual do Trabalho. E-mail: profvitorsalino@ gmail.com 
RESUMO: O presente trabalho tem como propósito analisar o julgamento antecipado parcial do mérito e o cumprimento provisório desta decisão, previstos no novo Código de Processo Civil, e a sua aplicação subsidiária ao Direito Processual do Trabalho, como instrumento de promoção do acesso à justiça na perspectiva contemporânea, que pressupõe uma prestação jurisdicional tempestiva e efetiva. A pesquisa inicia-se pela abordagem da denominada "crise da justiça", que gerou a busca por uma prestação jurisdicional mais célere e que produza efeitos concretos no mundo dos fatos, nos moldes do que fora garantido na lei. Para o alcance deste desiderato foram realizadas, nas últimas décadas, diversas reformas no processo civil comum, o que fomentou a análise da heterointegração normativa, especificamente do processo comum ao processo do trabalho, com a finalidade de valorizar a decisão de primeira instância e buscar a concretização dos direitos fundamentais trabalhistas.

PALAVRAS-CHAVE: julgamento antecipado parcial do mérito; cumprimento provisório de sentença; processo civil; processo do trabalho.

ABSTRACT: This study aims at analyzing the summary judgment on merits and the interim injunction of this decision provided for by the New Code of Civil Procedure and its subsidiary application to the Procedural Labor Law as a tool to promote the access to justice according to the contemporary perspective that presupposes a timely and effective adjudication. The search begins by approachingthe so-called "legal crisis" that led to the search for a faster adjudication that produces real effects in the world of facts according to what was assured by law. Toreach this goal several reforms in the ordinary civil procedure were made in the last decades, which fostered the analysis 
of a normative hetero-integration, specifically the common process and the labor process, in order to value the lower court decision and seek the achievement of fundamental labor rights.

KEYWORDS: summary judgment; interim injunction; civil procedure; procedural labor law.

\section{INTRODUÇÃO}

busca por uma prestação jurisdicional tempestiva e efetiva
vem permeando as discussões e estudos dos operadores do
Direito e a atuação do legislativo há algumas décadas, estan-
do estes atores sociais preocupados com a concretização do direito fundamental de acesso à justiça que, na perspectiva contemporânea, é entendido como aquele que permite à parte gozar do bem da vida, objeto do litígio, a tempo e a modo.

Neste contexto, a legislação processual civil, nos últimos anos, foi objeto de inúmeras reformas, em especial porque estava em descompasso com as características e anseios dos jurisdicionados na atualidade. Esta desarmonia acabou gerando a denominada "crise da justiça".

Como fruto destas alterações, estudos e exigências, foi apresentada proposta de um novo Código de Processo Civil (CPC - convertido na Lei $\mathrm{n}^{\circ} 13.105$, sancionada em 16 de março de 2015), pautado exatamente na efetividade e na celeridade da prestação jurisdicional.

Dentre as inovações, chama-se a atenção para aquela que passa a permitir o julgamento antecipado parcial do mérito em face de pedido incontroverso. 
A nova norma representa significativa alteração no sistema processual baseado na unicidade da decisão e vai ao encontro da busca por uma resposta rápida ao conflito em relação ao pedido que já possa ser julgado de plano e não necessita da fase de instrução probatória essencial para o esclarecimento daqueles controvertidos.

A tempestividade da resposta dada pelo Judiciário implica efetividade, em especial quando este pedido incontroverso julgado antecipadamente puder ser objeto de execução, definitiva ou provisória, segundo o modelo trazido pelo novo CPC, que segue a mesma linha do disposto no art. 475-O, $\$ 2$ o do CPC de 1973 (BRASIL, 1973).

Na seara laboral, em face da natureza existencial do crédito trabalhista, a alteração pode ser fonte de muitos benefícios para o obreiro que não tem condições de esperar o tempo do processo para gozar de seus direitos sem que isto lhe cause prejuízo.

O tempo do processo para o hipossuficiente que pleiteia uma verba essencial à sua subsistência pode representar um ônus excessivo e, na seara laboral, ele, em regra, é exclusivamente suportado pelo obreiro reclamante.

A aplicação subsidiária do julgamento antecipado parcial do mérito e do cumprimento desta decisão nos moldes do novo CPC ao Direito Processual do Trabalho (art. 769 da CLT) pode representar a valorização da decisão de primeira instância, em que o magistrado, em contato direto com as partes, pode analisar com mais profundidade as nuances e especificidades do caso concreto, permitindo que o demandante usufrua imediatamente de parte do bem da vida objeto do litígio.

Ainda, o uso subsidiário destas normas de processo civil na seara laboral pode representar a concretização de direitos fundamentais dos trabalhadores, que são imprescindíveis para a manutenção de uma vida digna.

Neste contexto, no presente trabalho, falar-se-á sobre o acesso à justiça 
na perspectiva contemporânea e os fatores que geraram a "crise da justiça". Em seguida, falar-se-á brevemente sobre o novo CPC e sua aplicação subsidiária ao Direito Processual do Trabalho. No tópico subsequente, analisar-se-á o pedido incontroverso objeto de julgamento antecipado parcial do mérito e, em seguida, a efetivação desta decisão, especificamente por meio da execução provisória também prevista no novo CPC. Na sequência, tratar-se-á da aplicação subsidiária de ambas as normas na seara laboral, como instrumento de valorização da decisão de primeiro grau e de concretização tempestiva e efetiva dos direitos fundamentais dos trabalhadores.

\section{NOTAS SOBRE A CRISE DA JUSTIÇA E A CON- CEPÇÃO CONTEMPORÂNEA DO DIREITO PREVISTO NO ART. $5^{\circ}$, XXXV DA CR/88}

Analisando o contexto atual, pode-se dizer que ele é caracterizado como um momento de crise. ${ }^{3}$ Não raro, depara-se com as expressões "crise econômica", "crise política", "crise da família”, "crise de valores", "crise de legitimidade", "crise de identidade" e, também, "crise da justiça".

A justiça, ou melhor, o modelo processual (civil) posto, ${ }^{4}$ construído a partir de outro contexto sociopolítico e econômico, entrou em crise, ${ }^{5}$ dentre

\footnotetext{
3 Segundo o vernáculo, dentre as várias acepções possíveis, o termo crise pode ser associado aos seguintes significados: "manifestação violenta e repentina de ruptura de equilíbrio"; "estado de dúvidas e incertezas"; "fase difícil, grave, na evolução das coisas, dos fatos, das ideias"; "momento perigoso ou decisivo"; "tensão, conflito"; "situação grave em que os acontecimentos da vida social, rompendo padrões tradicionais, perturbam a organização de alguns ou de todos os grupos integrados na sociedade" (FERREIRA, 2009, p. 576). 4 Ou seja, o Código de Processo Civil de 1973 (BRASIL, 1973).

5 Para Bedaque (2003), a Justiça entrou em crise, não só no Brasil, como na maioria dos países. E crise na Justiça implica, necessariamente, crise de justiça. Para ele, os fatores que contribuem para esse estado de verdadeira calamidade podem ser resumidos basicamente na exagerada demora e no alto custo do processo.
} 
outros fatores, exatamente porque não acompanhou as diversas mudanças ocorridas na sociedade.

Algumas dicotomias foram observadas: celeridade e instantaneidade no mundo dos fatos versus morosidade processual; anseio por aquilo que a lei prometeu versus tutela pelo equivalente pecuniário; conflitos de massa versus processo predominantemente individual; necessidades urgentes versus cognição plena e exauriente.

Os jurisdicionados passaram a questionar o modelo processual (civil) posto, pugnando, especificamente, por uma prestação jurisdicional mais tempestiva e efetiva:

a sociedade em geral clama por uma justiça rápida e eficaz, pois a sua morosidade se tornou fator principal de injustiça $[. .$.$] . Em consequência do clamor da sociedade,$ busca-se incessantemente, em matéria processual, a celeridade da prestação jurisdicional sob o fundamento da necessidade de efetividade do processo como verdadeiro corolário e implementação do acesso à justiça (FREITAS, 2008, p. 165-166).

A ausência daquelas características, resultado de um modelo processual baseado no tecnicismo e formalismo exacerbados, foi responsável pela chamada "crise da justiça", "caracterizada basicamente pela excessiva e intolerável demora com que os processos concluem os provimentos destinados a realizar a definitiva composição dos litígios" (THEODORO JUNIOR, 2008).

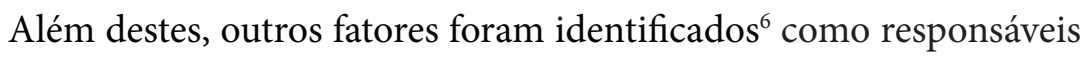
por este estado de coisas, a exemplo do alto custo do processo, aumento da litigiosidade diante do maior dinamismo e complexidade das relações sociais, inadequação da legislação para responder às novas necessidades da sociedade, baixo uso dos meios alternativos de resolução de conflitos e a

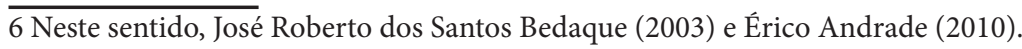


deficiente forma de utilização das novas tecnologias da informática.

O modelo processual e a prestação jurisdicional foram objeto de inúmeras críticas, que culminaram em uma onda de reformas legislativas focadas na adequação da norma instrumental às características da sociedade atual e aos anseios dos jurisdicionados e operadores do direito, com vistas a "abandonar a preocupação exclusiva com conceitos e formas, para dedicar-se à busca de mecanismos destinados a conferir à tutela jurisdicional o grau de efetividade que dela se espera" (THEORORO JUNIOR, 2006, p.19).

Neste contexto, foi desenvolvida uma nova concepção, denominada contemporânea, do direito e garantia fundamental de acesso à Justiça.

Este, além de estar positivado e de pressupor meios legais para o seu real exercício, deve proporcionar uma tutela jurisdicional efetiva e tempestiva, com observância do princípio constitucional do devido processo legal e seus consectários - contraditório, ampla defesa, motivação das decisões, duplo grau. Neste sentido, Marinoni aduz que:

O direito de ação, na sua concepção clássica e ainda presente em grande parte da doutrina do processo, não é mais do que o direito à solução do litígio ou o direito a uma sentença de mérito, seja ela de procedência ou de improcedência do pedido. Nesta dimensão, não há dúvida de que o direito de ação fica muito distante do direito à duração razoável do processo. Porém, quando o direito de ação é compreendido como o direito às técnicas processuais idôneas à viabilidade da obtenção das tutelas prometidas pelo direito material, ele se aproxima do direito à duração razoável do processo. Isto porque quando se considera o direito à obtenção da tutela do direito material se toma em conta a sua "efetividade" que também reclama a sua "tempestividade". Ao se deixar de lado a concepção clássica do direito de ação, atribui-se a ele significado de direito à tutela jurisdicional efetiva, inserindo-se no direito de ação o direito à tempestividade da prestação jurisdicional (MARINONI, 2009, p.83). 
Comungando do mesmo entendimento, Zavascki entende que o acesso à justiça não se resume ao direito de provocar o Poder Judiciário, mas compreende também a necessidade de que a tutela jurisdicional seja prestada em prazo razoável e produza reais efeitos no mundo dos fatos:

o dever imposto ao indivíduo de submeter-se obrigatoriamente à jurisdição estatal não pode representar um castigo. Pelo contrário: deve ter como contrapartida necessária o dever do Estado de garantir a utilidade da sentença, a aptidão de garantir, em caso de vitória, a efetiva e prática concretização da tutela. E não basta à prestação jurisdicional do Estado ser eficaz. Impõe-se seja também expedita, pois é inerente ao princípio da efetividade da jurisdição que o julgamento da demanda se dê em prazo razoável, "sem dilações indevidas". O direito fundamental à efetividade do processo - que se denomina também, genericamente, direito de acesso à justiça ou direito à ordem jurídica justa - compreende, em suma, não apenas o direito de provocar a atuação do Estado, mas também e principalmente o de obter, em prazo adequado, uma decisão justa e com potencial de atuar eficazmente no plano dos fatos (ZAVASCKI , 2009, p. 26, grifo nosso).

No que tange à tempestividade, vale ressaltar o importante e dicotômico papel que o tempo exerce no processo.

Isto porque, se, por um lado, a decisão, para ser proferida, demanda tempo para que o magistrado, com auxílio das partes, por meio do exercício do contraditório e da ampla defesa, forme o seu convencimento, de outro, "o tempo pode tornar o processo inócuo, tendo em vista que a resposta jurídica pode advir quando ela já nada mais pode resolver" (GONÇALVES, 2011, p. 285).

A morosidade é capaz de gerar descrença no Estado como pacificador de conflitos sociais, inibir o acesso à justiça e levar à ineficácia da tutela tardiamente concedida, por prolongar o estado de insatisfação do direito. 
Nas palavras de Marinoni:

A morosidade não só significa um peso muito grande para o litigante, como também inibe o acesso à justiça. A lentidão leva o cidadão a desacreditar no Poder Judiciário, o que é altamente nocivo aos fins de pacificação social da jurisdição, podendo até mesmo conduzir à deslegitimação do poder. Portanto, é tarefa da dogmática, preocupada com a construção do processo justo e isonômico - pensar em técnicas que justifiquem, racionalmente, a distribuição do tempo do processo. Floresce hoje uma tendência atenta à temática do acesso à justiça e, nesta perspectiva, podemos dizer que uma das questões mais preocupantes se revela no binômio "custo-morosidade", a demonstrar a falência do processo civil tradiciona (MARINONI, 1994, p. 27).

Sobre a importância da tempestividade da tutela jurisdicional como meio de promover o acesso à justiça sob a perspectiva contemporânea, aduz Bedaque que:

O fator tempo é, sem dúvida, muito importante para a efetividade do processo. A tutela jurisdicional tempestiva constitui valor amparado em sede constitucional. A garantia de acesso à justiça não se limita a assegurar a todos o mero poder de invocar a tutela jurisdicional do Estado. Representa, na verdade, a existência de instrumento adequado à realização do direito material em favor do seu titular, em tempo razoável, a fim de que ele possa realmente usufruir dos efeitos práticos daí decorrentes. E a demora excessiva normalmente compromete de forma definitiva esse escopo jurídico e social do processo (BEDAQUE, 2003, p. 386).

Já no que concerne à efetividade, esta diz respeito ao resultado alcançado por meio da prestação jurisdicional, que deve ser capaz de proporcionar uma tutela que se aproxime ao máximo daquilo que a parte 
obteria caso a norma tivesse sido cumprida a tempo e a modo por seu destinatário. Segundo Bueno, por efetividade do processo deve ser entendida, fundamentalmente:

1) busca pela efetividade da jurisdição e por um processo civil de resultados (assim, p.ex., o chamado "estatuto da tutela específica" dos arts. 461 e 461-A);

2) correlato fortalecimento dos poderes do juiz em busca dessa efetividade;

3) técnicas de aceleração da prestação da tutela jurisdicional (julgamento antecipado da lide; antecipação da tutela; execução por títulos extrajudiciais e processo monitório, p. ex.);

4) técnicas de compatibilização entre a cognição judicial e as diversas situações de direito material para melhor realizar o direito material;

5) ampliação à legitimidade ativa para a tutela de direitos e interesses coletivos (especialmente a correlação entre LACP e o CDC). (BUENO, 2004, p.11).

Na busca pela efetividade e tempestividade da prestação jurisdicional, o legislador passou a realizar diversas reformas no processo civil, como resposta à "crise da justiça" e aos anseios dos jurisdicionados.

O direito processual, bem como a ciência do direito, de um modo geral, está diante do desafio de repensar seus próprios conceitos, práticas, valores e paradigmas. ${ }^{7}$

Neste contexto de crise, inerente à pós-modernidade, que se traduz em um momento de reflexão, de crítica e de busca por novos paradigmas, que gerou reflexos no âmbito jurídico, especificamente processual, foi proposta

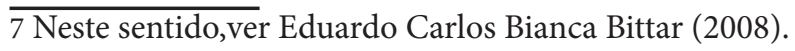


a reforma do CPC de 1973, cuja aplicação subsidiária ao Direito Processual do Trabalho, em alguns aspectos, é importante meio de concretização tempestiva e efetiva de direitos trabalhistas fundamentais.

\section{NOTAS SOBRE O NOVO CPC E SUA APLICAÇÃO SUBSIDIÁRIA AO DIREITO PROCESSUALDOTRABALHO}

O direito material estabelece normas destinadas a regular as relações na vida em sociedade, cuja observância é essencial para a paz social. Apesar de o ideal ser o cumprimento espontâneo das normas, exatamente para haver uma convivência harmônica, nem sempre isto acontece.

No momento em que há ameaça ou lesão à norma, nasce, para aquele que se sente ofendido, o direito de buscar a atuação da regra violada, o que é feito pelo Estado, ${ }^{8}$ que impediu a autotutela e avocou para si o monopólio da jurisdição.

A parte, por meio do exercício do direito de ação, materializado no processo, busca uma prestação jurisdicional do Estado, que, uma vez provocado, tem o poder-dever de dizer o direito no caso concreto.

Neste contexto, o processo passa a ter uma importância majorada, na medida em que é o instrumento de concretização do direito material.

Por este motivo, ganham relevo as discussões acerca do direito processual civil posto (CPC de 1973), caracterizado, como ressaltado, pelo formalismo e tecnicismo exacerbados, o que se justificou em um dado momento histórico, ${ }^{9}$ mas que acabou por gerar a morosidade e a baixa

8 Cumpre ressaltar a existência dos meios alternativos de resolução de conflitos, a exemplo da conciliação, a arbitragem e a mediação.

9 De acordo com Érico Andrade (2010, p. 18), "a saga do direito processual, como direito autônomo e desvinculado, teoricamente, do direito material, começou no século XIX - principalmente em torno da temática da teorização do direito de ação - e até hoje se encontra em plena 
efetividade da prestação jurisdicional, não respondendo mais aos anseios da sociedade atual, marcada pelo signo da instantaneidade e rapidez, globalização, incremento da tecnologia e massificação dos conflitos.

Essas características do século XXI influenciaram diretamente o direito processual, como expressão da relação dialética existente entre ambos. Isto porque, da mesma forma que o Direito destina-se a pautar a conduta humana, esta também propicia a modificação, a criação e a revogação da norma, no intuito de atualizá-la e não afastá-la da realidade.

Para tanto, em meados da década de 1990, o legislador, como já citado, passou a realizar diversas reformas esparsas na lei processual civil, visando tornar a tutela jurisdicional mais efetiva e tempestiva, pois o processo, com estas características, responde, não somente ao interesse privado das partes, mas gera mais confiança do jurisdicionado no Estado como pacificador de conflitos. De acordo com Watanabe:

Do conceitualismo e das abstrações dogmáticas que caracterizaram a ciência processual e que lhe deram foros de ciência autônoma, partem hoje os processualistas para a busca de um instrumentalismo mais efetivo do processo, dentro de uma ótica mais abrangente e mais penetrante de toda a problemática sócio-jurídica (WATANABE, 2000, p. 20).

Como fruto deste período de mudanças legislativas (e axiológicas),

evolução. A primeira preocupação da doutrina processual foi dar foros de disciplina autônoma ao processo, daí a necessidade de desvinculá-lo do direito material, entendê-lo em separado do direito material. Essa preocupação ou objetivo, justificável à época, levou a certa dose de exagero. $\mathrm{O}$ processo perde quase que totalmente a perspectiva de atuar o direito material e passa a ser pensado apenas em termos de técnica ou de instrumento técnico em si mesmo, desatento às necessidades próprias do direito material violado, que se pretende atuar por meio do processo. Com isso, perdura uma espécie de orientação tecnicista - também denominada, pela doutrina italiana, "burocratização do processo e do juiz" - em que os institutos processuais, abstratamente considerados, se sofisticaram ao extremo e acabaram por perder, cada vez mais, o contato com a realidade do direito material e com suas necessidades de atuação". 
em 2010, instituiu-se uma comissão externa de juristas responsável pela elaboração de um anteprojeto para um novo CPC, que, elaborado, foi subscrito, na íntegra, pelo Senador José Sarney, que figurou como autor do Projeto de Lei (PL) de no 166/10 de iniciativa do Senado.

Por força do disposto no art. 374 do Regimento Interno do Senado, foi instituída uma comissão temporária destinada a examinar o PL apresentado, que realizou, dentro das suas atribuições, audiências públicas para ampliar o debate acerca da reforma, ouvindo, não só operadores do direito, mas a sociedade como um todo. De acordo com o texto do anteprojeto do novo CPC:

A Comissão de Juristas encarregada de elaborar o anteprojeto de novo Código do Processo Civil, nomeada no final do mês de setembro de 2009 e presidida com brilho pelo Ministro Luiz Fux, do Superior Tribunal de Justiça, trabalhou arduamente para atender aos anseios dos cidadãos no sentido de garantir um novo Código de Processo Civil que privilegie a simplicidade da linguagem e da ação processual, a celeridade do processo e a efetividade do resultado da ação, além do estímulo à inovação e à modernização de procedimentos, garantindo o respeito ao devido processo legal. Esse o desafio da comissão: resgatar a crença no Judiciário e tornar realidade a promessa constitucional de uma justiça pronta e célere (BRASIL, 2010, grifo nosso).

Concluídos os trabalhos da Comissão e aprovado o PL do Senado nº166/2010, este foi enviado à Câmara dos Deputados, para revisão (art. 65 da CR/88) em dezembro de 2010 (PL 8.046/2010).

Nesta também foi constituída Comissão Especial para emitir parecer sobre o projeto, que foi objeto de inúmeras emendas, sendo discutido através de outras audiências públicas em diversos Estados. Em março de 
2014, a Câmara dos Deputados ${ }^{108}$ concluiu a votação do projeto do novo CPC com aprovação da redação final que foi enviada ao Senado.

A votação do PL foi encerrada no Senado em novembro de 2014, sendo o texto aprovado enviado à sanção presidencial, que ocorreu em 16 de março de 2015 (Lei no 13.105).

Dentre as reformas que objetivam uma prestação jurisdicional mais efetiva e tempestiva, citamos a previsão do julgamento antecipado parcial do mérito cabível em face de pedido incontroverso, ${ }^{119}$ in verbis:

Do julgamento antecipado parcial do mérito

Art. 356.O juiz decidirá parcialmente o mérito quando um ou mais dos pedidos formulados ou parcela deles:

I - mostrar-se incontroverso;

II - estiver em condições de imediato julgamento, nos termos do art. 355.

$\$ 1$ 으 decisão que julgar parcialmente o mérito poderá reconhecer a existência de obrigação líquida ou ilíquida.

$\$ 2^{\circ}$-A parte poderá liquidar ou executar, desde logo, a obrigação reconhecida na decisão que julgar parcialmente o mérito, independentemente de caução, ainda que haja recurso contra essa interposto.

$\$ 3$ 을 hipótese do $\$ 2^{\circ}$, se houver trânsito em julgado da decisão, a execução será definitiva.

$\$ 4^{\circ}$ A liquidação e o cumprimento da decisão que julgar parcialmente o mérito poderão ser processados em autos suplementares, a requerimento da parte ou a critério do juiz.

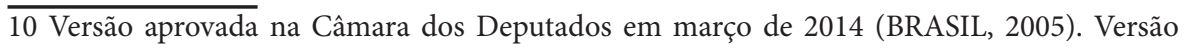
aprovada no Senado em dezembro de 2014 (BRASIL, 2010).

11 É importante salientar que o texto do projeto do novo CPC sofreu diversas mudanças no decorrer das votações. O pedido incontroverso foi objeto de Tutela da Evidência e agora de Julgamento Antecipado Parcial do Mérito. No atual Código, o assunto é tratado no art. 273, $\$ 6^{\circ}$, como espécie de antecipação de tutela. Sobre o tema, vide Moura Eça e Magalhães (2014). 
$\$ 5^{\circ} \mathrm{A}$ decisão proferida com base neste artigo é impugnável por agravo de instrumento (BRASIL, 2015).

Esta alteração modifica de forma expressiva a sistemática processual atual de unicidade da decisão.

O julgamento antecipado parcial do mérito deve ocorrer quando existente no processo um ou mais pedidos ou parcela dele incontroverso. A decisão apreciará apenas esta espécie de pedido, que já se encontra em condições de ser julgado e, após a instrução processual, haverá o julgamento dos demais pleitos.

A nova dinâmica permite uma separação dos pedidos, levando-se em consideração a necessidade, ou não, da fase de instrução, que serve exatamente para esclarecer os pedidos controvertidos.

Hoje, se presentes pedidos com ambas as características na mesma ação, não lhes é dispensado um tratamento diferenciado, devendo todos eles seguir a mesma marcha processual até o momento destinado à prolação da sentença.

Se, por um lado, o processo, em nome dos princípios da economia e da celeridade, permite à parte cumular pedidos, ele também deve oferecer um tratamento diferenciado em relação aos pedidos que necessitem da instrução probatória e àqueles que dela prescindem, por serem incontroversos.

Em alguns casos, as provas juntadas com a inicial e com a defesa já são suficientes para demonstrar que não há mais necessidade da fase de instrução, pois o direito já está robustamente comprovado, não havendo mais controvérsia, restando claro quem é o seu titular. De acordo com Doria: 
a controvérsia - que nada mais é que a situação decorrente da tomada de posições antagônicas pelas partes a respeito de determinado fato ou assunto - gera a necessidade de instrução e, consequentemente, de uma maior duração do processo civil. A conclusão acima deveria levar a outra, igualmente lógica: quanto menor fosse a controvérsia, menos tempo se faria necessário para o processo chegar ao seu final. Entretanto, nem sempre isso corresponde à verdade. (DORIA, 2004, p. 80).

E complementa a autora dizendo que:

O processo civil brasileiro, em função de determinadas formalidades e procedimentos já consagrados, acaba impondo às partes o ônus de aguardar o mesmo tempo para a apreciação das questões controversas e incontroversas. Com isso, faz aumentar a insatisfação dos jurisdicionados e surgir a sensação de descrédito. Esta crise, sem dúvida alguma, seria atenuada caso se considerasse que a controvérsia é a única razão para a duração do processo. (DORIA, 2004, p. 80).

Dentro da dinâmica do CPC de 1973, em regra é sempre o autor que suporta o ônus da espera, pois, independentemente de ter razão ou não, de seu pedido ser controverso ou incontroverso, é ele quem se vê privado do bem da vida objeto do litígio, enquanto o réu o mantém no seu patrimônio, deixando de satisfazer o direito do demandante.

O texto do art. 356 do novo CPC representa um progresso e a quebra do dogma da unicidade da decisão, tão caro à tempestividade e à efetividade da prestação jurisdicional, em especial quando o objeto do conflito diz respeito a direitos fundamentais como os trabalhistas. 


\section{O PEDIDO INCONTROVERSO OBJETO DO JUL- GAMENTO ANTECIPADO PARCIAL DO MÉRITO}

A demora na prestação jurisdicional oferece prejuízo para aqueles direitos que, de plano, já se mostram devidos, representando a espera um ônus excessivo para o demandante. Isto porque "o simples fato de o direito permanecer insatisfeito durante todo o tempo necessário ao desenvolvimento do processo cognitivo já configura dano ao seu titular" (BEDAQUE, 2003, p. 22).

O tempo necessário para que se encontre o titular do direito dito lesado ou ameaçado de lesão por si só pode ser fonte de dano para aquele que o suporta,especialmente quando a instrução probatória mostra-se desnecessária diante de pleitos que dela não necessitam.

O tempo também pode ser extremamente prejudicial quando o crédito que se busca judicialmente tem natureza existencial (direito fundamental) e o demandante é hipossuficiente.

Quanto antes o autor puder usufruir o bem da vida, objeto do litígio, maior correspondência haverá entre a solução dada pelo órgão jurisdicional e o disposto na lei material, como se o destinatário da norma a houvesse espontaneamente cumprido. Quanto maior a equivalência entre ambos, mais o processo será efetivo.

Em face da inexistência de controvérsia de determinado pedido, o tempo necessário para a discussão e análise das demais questões que necessitam ser comprovadas acaba impondo uma espécie de castigo ao demandante e ferindo o princípio da igualdade, pois trata da mesma maneira situações diferentes.

Como ressaltado, em regra é sempre o autor que suporta o ônus da espera, independentemente de seu pedido ser ou não controvertido, 
sistemática que beneficia o réu e é alheia à necessidade de tratamento diferenciado para situações desiguais (princípio da igualdade).

Neste contexto, emerge o julgamento antecipado parcial do mérito, instrumento de promoção de uma tutela jurisdicional diferenciada, tempestiva e efetiva, para os pedidos incontroversos, que "exigem procedimentos que com eles sejam compatíveis, e não procedimentos neutros e indiferentes a estas situações" (MARINONI, 2002, p. 9).

Por meio da antecipação do momento de julgamento do pedido que não necessita da fase de instrução, porque incontroverso, é possível adaptar a dinâmica processual a esta realidade.

Nas palavras de Marinoni (2002, p. 139), "o autor que evidencia parcela do direito que postula em juízo não pode ser prejudicado pelo tempo necessário à cognição do restante" e o princípio chiovendiano della unità e unicità della decisione há muito não se concilia com a leitura contemporânea do princípio que determina que o processo não pode prejudicar o autor que tem razão. Assim:

Se um dos pedidos apresentados pelo autor está maduro para julgamento, seja porque diz respeito apenas à matéria de direito, seja porque independe de instrução dilatória, a necessidade, cada vez mais premente, de uma prestação jurisdicional célere e efetiva, justifica a quebra do velho princípio da "unità e unicità della decisione”. (MARINONI, 2002, p. 139).

O pedido incontroverso, nos termos do texto do novo CPC, passaria a ser objeto de um julgamento antecipado parcial fundado em cognição plena e exauriente porque não haveria mais necessidade de produção de provas em relação a ele. A decisão é impugnável via agravo de instrumento.

O julgamento antecipado parcial do mérito seria um meio de promoção dos princípios da efetividade e da tempestividade da prestação 
jurisdicional, repartindo entre as partes o tempo do processo, sendo uma forma de atenuar o "dano marginal" que é acarretado a todo autor que tem razão.

O pressuposto do julgamento antecipado parcial do mérito é a existência de um (ou mais) pedido em condições de ser imediatamente julgado e outro (ou outros) que necessite da fase de instrução probatória. Sobre o julgamento antecipado da lide, Bedaque assevera que:

Tais situações indicam ser dispensável a produção de novas provas, pois a matéria fática é incontroversa em decorrência da revelia ou já existem elementos suficientes para a formação do convencimento do juiz. A cognição, nesses casos, é exauriente e implica entrega da tutela jurisdicional inicialmente pleiteada e de natureza satisfativa, destinada a produzir efeitos irreversíveis no plano material. (BEDAQUE, 2003, p. 366).

Nas palavras de Theodoro Junior:

se a questão de fato gira em torno apenas de interpretação de documentos já produzidos pelas partes; se não há requerimento de provas orais; se os fatos arrolados pelas partes são incontroversos; e ainda se não houve contestação, o que também leva à incontrovérsia dos fatos da inicial e à sua admissão como verdadeiros (art. 319); o juiz não pode promover a audiência de instrução e julgamento, porque estaria determinando a realização de ato inútil e, até mesmo, contrário ao espírito do Código. Observe-se que o art. 334 expressamente dispõe que não dependem de prova os fatos "admitidos, no processo, como incontroversos" e aqueles "em cujo favor milita a presunção legal de existência ou de veracidade" (n. III e IV). Por outro lado, harmoniza-se com a preocupação de celeridade que deve presidir à prestação jurisdicional, e que encontra regra pertinente no art. 125, II, que manda o juiz "velar pela rápida solução do litígio", e no art. 130 que recomenda indeferir "as 
diligências inúteis ou meramente protelatórias". (THEODORO JÚNIOR'2006, p. 447).

O julgamento antecipado parcial do mérito pressupõe a existência de um pedido, ou parcela dele, incontroverso, ostentando esta qualidade "não apenas o que não foi contestado ou foi reconhecido, mas o pedido (ou sua parte) que estiver maduro para julgamento" (MARINONI, 2002, p. 159), devendo seu significado

[...] ser buscado no art. 331, $\$ 2^{\circ}$. Ao tratar da audiência preliminar, diz esse artigo que, se não for obtida a conciliação, o juiz "fixará os pontos controvertidos", decidirá as eventuais questões pendentes, e determinará as provas a serem produzidas, designando, se necessário, audiência de instrução e julgamento. Na audiência preliminar, o juiz pode chegar à conclusão que parcela da demanda, apesar de contestada, não precisa ser esclarecida mediante prova testemunhal ou pericial. Nesse caso, apenas a outra parte da demanda deverá ser fixada como controvertida e somente sobre ela deverá ser determinada a produção de prova. (MARINONI, 2009, p.286).

Incontroverso, para Zavascki, é o pedido indiscutível, ou seja, aquele sobre o qual não é possível travar qualquer discussão; mesmo que se tente, a defesa será infundada, pois não há argumentos capazes de infirmar o pleito. "Além da ausência de controvérsia entre as partes, somente poderá ser tido como incontroverso o pedido que, na convicção do juiz, for verossímil. 'Incontroverso', em suma, não é 'indiscutido', mas sim o indiscutível” (ZAVASCKI, 2009, p.111). O autor complementa dizendo que:

pode-se dar ao conceito de pedido incontroverso um sentido ampliado,mais afinado com uma interpretação teleológica da norma: será considerado incontroverso 
o pedido, mesmo contestado, quando os fundamentos da contestação sejam evidentemente descabidos ou improcedentes. Em outras palavras: quando não haja contestação séria. Essa ausência de seriedade ou razoabilidade, todavia, há de ser medida, não apenas a partir da conviçção pessoal do juiz, mas à luz de critérios objetivos fornecidos pelo próprio sistema de processo. (ZAVASCKI, 2009, p. 111).

Bueno, a seu turno, entende que incontroverso é o que não precisa de prova complementar, ficando demonstrado, de plano:

Pedido incontroverso tem sentido bem claro na dinâmica probatória do processo civil: é aquele que não depende de prova complementar. De fato, a "incontrovérsia" de um ou mais dos pedidos dispensa a parte contrária do ônus da prova (art.334, II e III, c/c o art. 330, I). Trata-se, pois, daquele que foi já suficientemente comprovado. Não se trata aqui de uma suficiência probatória momentânea (verossimilhança), mas definitiva (incontrovérsia). A análise desse pressuposto revela que a lei exige mais do que o caput para a concessão da "tutela antecipada". Fosse mera verossimilhança, como no caput, e seria lícita a produção ulterior de prova para infirmar o grau de conviç̧ão já formado no espírito do magistrado. Não no $₫ 6^{\circ}$, entretanto. (BUENO, 2004, p. 49).

Ele ainda questiona se a incontrovérsia em questão diz respeito aos pedidos cumulados (ou parte deles) ou, bem diferentemente, à causa de pedir, concluindo que são os fatos subjacentes aos pedidos que lhe dão embasamento, que independem de prova ulterior, e não propriamente o pedido (em si mesmo considerado), que deve ser incontroverso.

Entende-se, seguindo esta linha de raciocínio, que a incontrovérsia diz respeito aos fatos que embasam o pedido formulado pelo demandante, que se mostram, de plano e do cotejo da inicial com a defesa, compro- 
vados, fazendo o pedido maduro para julgamento. Em relação a ele, não há controvérsia séria, mas apenas uma contestação sem fundamento que visa tão somente protelar a demanda.

Neste sentido, também o art. 334 do CPC de 1973 (art. 374 do novo $\mathrm{CPC}$ ), que elenca hipóteses de fatos que não dependem de provas, dentre os quais inclui os incontroversos, ao lado dos notórios, dos afirmados por uma parte e confessados pela outra e daqueles em cujo favor milita presunção legal de existência ou de veracidade.

Paralelamente aos conceitos formulados por parte da doutrina, sucintamente demonstrados, a noção do que seja incontroverso pode ser buscada em outras ações ou procedimentos, a exemplo do direito líquido e certo do mandado de segurança e da prova pré-constituída exigida nas ações monitória, possessória e de alimentos.

A despeito da ausência de uma conceituação pacífica sobre o que seja o pedido incontroverso, paulatinamente, doutrina e jurisprudência incumbir-se-ão de traçar os seus limites, permitindo, assim, que o juiz possa entregar à parte, de maneira tempestiva e efetiva, a tutela deste direito por meio do julgamento antecipado parcial do mérito.

Para que esta decisão possa gerar efeitos concretos no mundo dos fatos, pode ser utilizada a execução provisória (artigos 520, 521 e 522 do novo $\mathrm{CPC},{ }^{1210}$ semelhantes ao art. $475-\mathrm{O}, \$ 2^{\circ}$ do CPC de 1973), denomi-

12 Art. 520. O cumprimento provisório da sentença impugnada por recurso desprovido de efeito suspensivo será realizado da mesma forma que o cumprimento definitivo, sujeitando-se ao seguinte regime:I - corre por iniciativa e responsabilidade do exequente, que se obriga, se a sentença for reformada, a reparar os danos que o executado haja sofrido;II - fica sem efeito, sobrevindo decisão que modifique ou anule a sentença objeto da execução, restituindo-se as partes ao estado anterior e liquidando-se eventuais prejuízos nos mesmos autos;III - se a sentença objeto de cumprimento provisório for modificada ou anulada apenas em parte, somente nesta ficará sem efeito a execução;IV - o levantamento de depósito em dinheiro e a prática de atos que importem transferência de posse ou alienação de propriedade ou de outro direito real, ou dos quais possa resultar grave dano ao executado, dependem de caução suficiente e idônea, arbitrada de plano pelo juiz e prestada nos próprios autos. $\$ 11^{\circ}$ No cumprimento provisório da 
nada cumprimento provisório de sentença que reconheça a exigibilidade de obrigação de pagar quantia certa.

Neste contexto, defende-se a aplicação subsidiária destes dois institutos à seara laboral, nos termos do art. 769 da CLT, como forma de valorização da decisão de primeira instância e promoção do acesso a tempo e a modo dos direitos fundamentais trabalhistas.

sentença, o executado poderá apresentar impugnação, se quiser, nos termos do art. 525.\$2ํㅡㄴ multa e os honorários a que se refere o $\$ 1$ ㅇdo art. 523 são devidos no cumprimento provisório de sentença condenatória ao pagamento de quantia certa. $\$ 3$ - $S e$ o executado comparecer tempestivamente e depositar o valor, com a finalidade de isentar-se da multa, o ato não será havido como incompatível com o recurso por ele interposto. $\$ 4^{\circ} \mathrm{A}$ restituição ao estado anterior a que se refere o inciso II não implica o desfazimento da transferência de posse ou da alienação de propriedade ou de outro direito real eventualmente já realizada, ressalvado, sempre, o direito

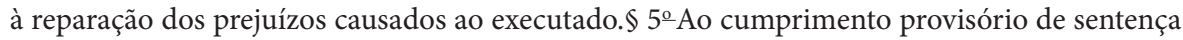
que reconheça obrigação de fazer, de não fazer ou de dar coisa aplica-se, no que couber, o disposto neste Capítulo.

Art. 521.A caução prevista no inciso IV do art. 520 poderá ser dispensada nos casos em que:I o crédito for de natureza alimentar, independentemente de sua origem;II - o credor demonstrar situação de necessidade;III - pender o agravo fundado nos incisos II e III do art. 1.042;IV - a sentença a ser provisoriamente cumprida estiver em consonância com súmula da jurisprudência do Supremo Tribunal Federal ou do Superior Tribunal de Justiça ou em conformidade com acórdão proferido no julgamento de casos repetitivos.Parágrafo único.A exigência de caução será mantida quando da dispensa possa resultar manifesto risco de grave dano de difícil ou incerta reparação.

Art. 522.O cumprimento provisório da sentença será requerido por petição dirigida ao juízo competente.Parágrafo único.Não sendo eletrônicos os autos, a petição será acompanhada de cópias das seguintes peças do processo, cuja autenticidade poderá ser certificada pelo próprio advogado, sob sua responsabilidade pessoal:I - decisão exequenda;II - certidão de interposição do recurso não dotado de efeito suspensivo;III - procurações outorgadas pelas partes;IV - decisão de habilitação, se for o caso;V - facultativamente, outras peças processuais consideradas necessárias para demonstrar a existência do crédito. 


\section{SOBRE O CUMPRIMENTO PROVISÓRIO DO JUL- GAMENTO ANTECIPADO PARCIAL DO MÉRITO E SUA APLICAÇÃO SUBSIDIÁRIA AO DIREITO PROCESSUAL DO TRABALHO}

O julgamento antecipado parcial do mérito representa, conforme buscou-se demonstrar, uma forma de promover uma prestação jurisdicional tempestiva e efetiva, representando uma resposta do legislador às peculiaridades do pedido objeto da ação, pois, com o passar do tempo, percebeu-se que não se justificava fazer a parte esperar para gozar de um direito decorrente de pedido incontroverso, que, como tal, não necessitava da fase de instrução probatória.

A decisão que permite à parte gozar antecipadamente do seu direito deve ser capaz de promover resultado útil no mundo dos fatos, sob pena de tornar-se inócua.

A parte deve, efetivamente, poder usufruir, de maneira antecipada, da decisão que, de outro modo, só seria prolatada ao final da fase de conhecimento. E, "se a tutela depende de atos executivos, ela somente é efetivamente entregue ao seu destinatário no momento em que é 'executada"' (MARINONI, 2002, p. 202). Sobre a execução, vale a pena transcrever as palavras de Bueno:

O termo "execução" deve ser entendido de forma mais ampla do que, tradicionalmente, lhe empresta a doutrina tradicional. Não há por que, com os olhos voltados ao sistema processual civil hoje vigente, atrelar-se efeitos executivos a uma determinada e específica classe de decisões jurisdicionais, qual seja, a de sentenças ou acórdãos de mérito condenatórios. Penso que também uma decisão declaratória, constitutiva, mandamental ou executiva, ao lado das decisões condenatórias, possam ser também objeto de uma "execu- 
ção" e, se ainda pender algum recurso de exame, ser esta execução "provisória". (BUENO, 2006, p.40).

Em regra, o julgamento antecipado da lide extingue o processo com resolução de mérito (art. 355 do novo CPCe art. 330 do CPCde 1973), e esta decisão pode ser objeto de apelação e de execução. ${ }^{1311}$

Já o julgamento antecipado parcial do mérito, segundo o novo CPC, é impugnável via agravo de instrumento, o que faz crer tratar-se de decisão interlocutória, mas o texto permite a execução provisória ou definitiva desta decisão.

Em se tratando de prestação de pagar a quantia certa, e havendo recurso pendente contra a decisão que julgou antecipada e parcialmente o mérito, aplica-se o procedimento da execução provisória, antecedido, se for o caso,da liquidação. De acordo com Pimenta:

o juiz do trabalho, diante da incontrovérsia (decorrente dos termos da defesa apresentada pelo reclamado) do direito do reclamante a determinado valor líquido a título de verbas rescisórias, mesmo que ainda persista controvérsia entre as partes a respeito dos demais pedidos iniciais formulados pelo autor (versando, por exemplo, sobre horas extras não pagas e suas incidências), conceda desde logo, na inauguração da audiência, a antecipação da tutela de mérito relativa ao primeiro daqueles pedidos iniciais (ou até mesmo da parcela incontroversa deste pedido), mediante decisão mandamental e executiva lato sensu que veicule ordem ao demandado para que desde logo pague, no prazo razoável que então fixar, sob pena de incidência das medidas coercitivas que fixar (e à luz do que estabelecem o inciso $\mathrm{V}$ e o parágrafo único do art. 14 do CPC, introduzidos pela Lei n. 10.358/01) ou de imediata execução provisória daquela quantia, através

13 Joel Dias Figueira Júnior, Flávio Cheim Jorge, Marcelo Abelha Rodrigues e Fredie Didier Júnior, citados por José Henrique Mouta Araújo (2004), discorrem sobre o julgamento antecipado parcial da lide, decorrente de pedido incontroverso, que desafia execução imediata. 
dos meios sub-rogatórios idôneos para tanto. (PIMENTA, 2004, p. 372).

O julgamento antecipado parcial do mérito é instrumento de combate da morosidade da prestação jurisdicional e de promoção do princípio da efetividade e, para realmente alcançar seu desiderato, deve ser passível de execução.

Dado o potencial do instituto em análise, defende-se a transferência de toda esta dinâmica para o processo do trabalho, o que encontra guarida no art. 769 da Consolidação das Leis do Trabalho (CLT) (BRASIL, 1943) e no artigo 15 do novo CPC (BRASIL, 2015), ${ }^{1412}$ pois não há norma específica sobre julgamento antecipado parcial da lide nas normas celetistas e o seu regramento sobre execução provisória é menos efetivo do que aquele do processo civil comum, havendo, no caso, uma lacuna ontológica. ${ }^{1513}$

Insta salientar que, como se sabe, as decisões interlocutórias na seara laboral não são impugnáveis de plano, devendo a parte registrar seu protesto nos autos e, quando da sentença, recorrer daquela decisão. ${ }^{1614}$

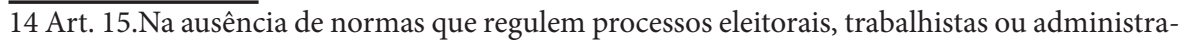
tivos, as disposições deste Código lhes serão aplicadas supletiva e subsidiariamente.

15 De acordo com Bezerra Leite (2007) "a heterointegração dos dois subsistemas (processo civil e trabalhista) pressupõe a interpretação evolutiva do art. 769 da CLT, para permitir a aplicação subsidiária do CPC não somente na hipótese (tradicional) de lacuna normativa do processo laboral, mas também quando a norma do processo trabalhista apresentar manifesto envelhecimento que, na prática, impede ou dificulta a prestação jurisdicional justa e efetiva deste processo especializado. [...] são três as principais espécies de lacunas: $1^{\text {a }}$ ) normativa, quando há ausência de norma sobre determinado caso; $2^{\mathrm{a}}$ ) ontológica, há norma, mas ela não corresponde aos fatos sociais. É o que ocorre, v. g., quando o grande desenvolvimento das relações sociais e o progresso acarretarem o ancilosamento da norma positiva; $3^{a}$ ) axiológica, existe a norma, mas ela se revela injusta, isto é, existe um preceito normativo, mas se for aplicado, a solução do caso será insatisfatória ou injusta. [...] Para colmatar as lacunas ontológica e axiológica do art. 769 da CLT torna-se necessária uma nova hermenêutica que propicie um novo sentido ao seu conteúdo devido ao peso dos princípios constitucionais do acesso efetivo à justiça que determinam a utilização dos meios necessários para abreviar a duração do processo".

16 Art. 893 da CLT - Das decisões são admissíveis os seguintes recursos: $\$ 1^{\circ}$ - Os incidentes do processo são resolvidos pelo próprio Juízo ou Tribunal, admitindo-se a apreciação do mereci- 
Entretanto, tal fato não exclui a possibilidade de julgar-se antecipada e parcialmente o mérito e executar-se tal decisão, em especial porque proferida com base em cognição plena e exauriente.

Mas registre-se que esta execução provisória no âmbito do processo do trabalho não seguiria a norma do art. 899 da CLT, que a limita à penhora.

Entende-se, na linha do que defende Carlos Henrique Bezerra Leite, que deve ser feita uma "interpretação evolutiva do art. 899 da CLT, pois este, no particular, apresenta nítido envelhecimento em relação ao processo civil” (2008, p.935), ou seja, deve ser aplicada a norma processual civil a partir da compreensão do conceito da citada lacuna ontológica.

O contexto histórico deve ser apreendido pelo aplicador da norma, que se torna sensível ao fato de que muitas disposições legais não correspondem mais à realidade.

Assim, ainda que a CLT contemple a execução provisória, a aplicação desta norma pode acabar sendo prejudicial àquele que teve o seu direito reconhecido, sendo necessária a busca no ordenamento jurídico de outro preceito que ofereça uma resposta melhor, dentro da perspectiva de efetividade e da tempestividade da tutela jurisdicional. Nas palavras de Marinoni:

O juiz, por sua vez, ao interpretar as normas processuais, deve estar ciente de que sua função é comprometida com o conteúdo do direito do seu momento histórico. Não cabe a ele, assim, aplicar friamente a lei, quando esta possa conduzir a resultados desvirtuados, seja porque não foi adequadamente elaborada, seja porque não mais corresponde às necessidades sociais. $\mathrm{O}$ juiz apreende $\mathrm{o}$ conteúdo do direito do momento em que vive sabe reconhecer o texto de lei que não corresponde às expectativas sociais e extrair da Constituição os elementos que lhe permitem decidir de modo a fazer valer o conteúdo do direito do seu tempo. (MARINONI, 2002, p.20).

mento das decisões interlocutórias somente em recursos da decisão definitiva. 
Tendo em vista o descompasso do art. 899 da CLT com a realidade extraprocessual contemporânea e os escopos da jurisdição, entende-se pela aplicabilidade da execução provisória (cumprimento provisório de sentença) prevista no processo comum ao processo do trabalho, pois:

[...] a atual disciplina da execução provisória no processo civil é mais avançada do que aquela prevista na CLT. Com isso, por meio de interpretação sistemática e teleológica, fundada nos valores e princípios constitucionais, defende-se a aplicabilidade das disposições sobre o tema, prevista no CPC, que estejam em consonância com a efetividade da tutela jurisdicional. (GARCIA, 2012, p. 674).

Ainda que não haja lacuna normativa na CLT no que tange à execução provisória, argumento de parte da doutrina que nega a aplicação subsidiária do processo civil comum, entende-se que a análise do assunto deve ser ampliada, considerando as outras espécies de lacuna, especificamente a lacuna ontológica.

Quer parecer que a norma celetista encontra-se ultrapassada em relação à norma processual civil, posto que esta, como se buscou demonstrar, sofreu inúmeras reformas nos últimos tempos, com o escopo de promover uma prestação jurisdicional mais tempestiva e efetiva. Reformas que culminaram no novo CPC.

$\mathrm{O}$ art. 769 da CLT, neste contexto, deve ser lido, não só sob o prisma da ausência de norma, mas das outras espécies de lacunas, o que reforça a idéia de aplicação subsidiária da execução provisória do processo civil ao processo do trabalho. Nas palavras de Chaves:

A heterointegração faz-se necessária por uma questão de simetria e paralelismo, até mesmo porque o objetivo do instituto em foco se prende à celeridade e economia 
processuais, postulados ainda mais presentes na principiologia do Direito Processual do Trabalho, intimamente ligada com a sua matriz material, que envolve direitos e créditos socialmente em destaque, considerados, estes últimos, privilegiadíssimos pela ordem jurídica vigente. (CHAVES, 2007b, p. 213).

Com entendimento convergente, assevera Schiavi:

Não pode o Juiz do Trabalho fechar os olhos para normas de Direito Processual Civil mais efetivas que a CLT e se omitir sob o argumento deque a legislação processual do trabalho não é omissa, pois estão em jogo interesses muito maiores que a aplicação da legislação processual trabalhista mas, sim a importância do Direito Processual do Trabalho, como sendo um instrumento célere, efetivo, confiável, que garanta, acima de tudo, a efetividade da legislação processual trabalhista e a dignidade da pessoa humana. (SCHIAVI, 2010, p. 1056-1057).

No mesmo sentido, o enunciado 69 da $1^{\text {a }}$ Jornada de Direito Material e Processual do Trabalho, ocorrida em Brasília em 2007, que, apesar de não ser fonte do direito, expressa o pensamento dos operadores do Direito do Trabalho. ${ }^{1715}$

Partindo da premissa da aplicabilidade subsidiária da execução provisória do processo comum à seara laboral, defende-se o cabimento

17 EXECUÇÃO PROVISÓRIA. APLICABILIDADE DO ART. 475-O DO CPC NO PROCESSO DO TRABALHO. I - A expressão “....até a penhora...” constante da Consolidação das Leis do Trabalho, art. 899, é meramente referencial e não limita a execução provisória no âmbito do direito processual do trabalho, sendo plenamente aplicável o disposto no Código de Processo Civil, art. 475-O. II - Na execução provisória trabalhista é admissível a penhora de dinheiro, mesmo que indicados outros bens. Adequação do postulado da execução menos gravosa ao executado aos princípios da razoável duração do processo e da efetividade. III - É possível a liberação de valores em execução provisória, desde que verificada alguma das hipóteses do artigo 475-O, $\$ 2^{\circ}$, do Código de Processo Civil, sempre que o recurso interposto esteja em contrariedade com Súmula ou Orientação Jurisprudencial, bem como na pendência de agravo de instrumento no TST. (BRASIL, 2007). 
completo da norma, segundo a qual se dispensa a caução - o levantamento de depósito em dinheiro e a prática de atos que importem transferência de posse ou alienação de propriedade ou de outro direito real, ou dos quais possa resultar grave dano ao executado - nas hipóteses de crédito de natureza alimentar, independente da sua origem, e o credor demonstrar situação de necessidade. ${ }^{1816}$

De acordo com a norma processual civil, o levantamento de depósito em dinheiro e a prática de atos que importem alienação de propriedade ou dos quais possa resultar grave dano ao executado, dependem de caução suficiente e idônea, pois,por meio desta garantia, protege-se o réu caso, eventualmente, ao final da ação, conclua-se que ele tem razão.

Isto porque, se o demandante for hipossuficiente, caso seja permitida a execução provisória que importe levantamento de depósito em dinheiro ou atos de expropriação dos bens do executado e, posteriormente, o resultado final do processo lhe seja desfavorável, este poderia não ter meios de restituir o que lhe fora entregue ou ressarcir os prejuízos eventualmente sofridos pelo réu.

A forma de contrabalancear os interesses das partes é exigindo a caução; assim, tanto autor quanto réu ficariam resguardados, mesmo diante de levantamento de depósito em dinheiro ou expropriação de bens.

Entretanto, a própria norma mitiga a obrigatoriedade de se exigir a garantia,conforme citado, quando o crédito for de natureza alimentar e a parte demonstrar situação de necessidade.

Como se sabe, o crédito trabalhista possui natureza alimentar (existencial) nos termos do art. $100, \S 1^{\circ}$, da CR/88, destinando-se o salário às necessidades essenciais do ser humano. Logo, estaria preenchido o primeiro

18 Ressalte-se que, neste aspecto, o novo CPC exclui a limitação de "até 60 salários mínimos" prevista no art. 475-0 do CPC de 1973. 
requisito.

O requisito da situação de necessidade, por ser um conceito aberto, vai depender do caso concreto, ou seja, da prova produzida sobre as reais condições econômicas da parte. $\mathrm{O}$ fato de o reclamante estar desempregado e não ter fonte de sustento pode ser um indicativo desta situação.

A liberação de certo valor para o reclamante, logo no início do processo, decorrente da execução provisória de decisão que julgou parcial e antecipadamente o mérito, representa um passo importante no caminho da efetividade e tempestividade da tutela jurisdicional.

A parte que puder contar, de plano, com uma quantia em dinheiro (parte do pleiteado) tem mais condições de aguardar o desenvolvimento do processo sem sofrer tanto com a demora e com as pressões decorrentes da necessidade financeira. Nas palavras de Dalazen:

óbvio que se há um processo em que a morosidade é absolutamente intolerável tal se dá no trabalhista. Nenhum outro convive tão de perto com a pobreza, quando não com a miséria. Logo, retardar a prestação jurisdicional no processo do trabalho pode significar o comprometimento da fonte única de subsistência de uma pessoa e sua família. É denegação de justiça qualificada! (DALAZEN, 1997, p. 39).

O ex adverso, por sua vez, que também de plano tiver que cumprir com sua obrigação, pagando parte do que deve, não contará tanto com a demora do processo como seu aliado. Conforme afirma Marinoni:

A lentidão da justiça [...] é de interesse de alguns. [...] Na realidade, a demora do processo é um benefício para o economicamente mais forte, que se torna, no Brasil, um litigante habitual em homenagem à inefetividade da justiça. Basta lembrarmos o que se verifica na Justiça do Trabalho, onde os economicamente mais fortes, desdenhando da justiça, apostam na lentidão da prestação ju- 
risdicional, obrigando aos trabalhadores realizar acordos quase sempre dês razoáveis. Será que alguém ainda acredita que a justiça é efetiva ou inefetiva, ou será que ela é sempre efetiva para alguns? (MARINONI, 1994, p. 2).

Quer parecer que, quanto mais a tutela jurisdicional for tempestiva e efetiva, menos o direito material será descumprido, e, em última análise, mais efetivo ele também será, em uma espécie de círculo virtuoso de ações. Assim,

quanto mais efetiva a máquina jurisdicional, menos ela vai ter que atuar concretamente, no futuro ou a médio prazo. Simetricamente, quanto mais os destinatários das normas jurídicas souberem que só lhes resta cumprir a lei, por absoluta falta de melhor alternativa, menos será necessário o acionamento da máquina jurisdicional e maiores eficácia e efetividade terão as normas jurídicas materiais. (PIMENTA, 2004, p. 342).

Neste contexto, reitera-se o entendimento acerca do potencial das citadas normas do processo civil para promover o direito fundamental de acesso à justiça na perspectiva contemporânea que pressupõe efetividade e tempestividade da prestação jurisdicional, especialmente na seara laboral, em face da natureza existencial do crédito trabalhista, no qual aquelas devem ser subsidiariamente aplicadas.

\section{CONCLUSÃO}

O descompasso entre o modelo processual (CPC 1973), os anseios dos jurisdicionados e as características da sociedade contemporânea foram alguns dos fatores que geraram a crise da justiça, combatida por meio de 
reformas processuais baseadas na busca pela efetividade e tempestividade da prestação jurisdicional.

Esta função estatal, realizada com as citadas características, traduz a concepção moderna do direito e garantia fundamental de acesso à justiça, ou seja, não basta o reconhecimento legal do referido direito e a disponibilização de meios para que a parte, de fato, possa ir à justiça, devendo a prestação jurisdicional ser efetiva e tempestiva.

Visando harmonizar as alterações esparsas e dotar o processo civil de instrumentos para que ele ostente os atributos acima referidos, foi proposto um projeto de lei para a edição de um novo Código de Processo Civil que, em dezembro de 2014, foi aprovado pelo Senado e, em março de 2015, sancionado pela Presidenta (Lei no 13.105).

Dentre as novidades propostas, chama-se a atenção para aquela que permite o julgamento antecipado parcial do mérito, por ser capaz de repartir entre as partes o ônus do tempo do processo, dando tratamento diferenciado e condizente com as características de cada pedido, ou seja, só se submete à fase de instrução o pedido controvertido, podendo ser julgado de plano aquele incontroverso.

De acordo com a nova sistemática, esta decisão seria interlocutória, impugnável por meio do agravo de instrumento, e representaria a quebra do dogma da unicidade da decisão.

Transportando esta dinâmica para o Direito Processual do Trabalho, face a sua compatibilidade nos termos do art. 769 da CLT e 15 do novo CPC, vê-se o julgamento antecipado parcial como instrumento com enorme potencial para proporcionar a entrega tempestiva da prestação jurisdicional trabalhista e, consequentemente, efetiva, qualidades tão caras à seara laboral, em face da natureza alimentar (existencial) do crédito trabalhista.

A concretização e a maximização dos resultados deste julgamento 
antecipado parcial são passíveis de serem alcançadas por meio do procedimento da execução provisória previsto no processo civil comum, que também pode ser aplicado subsidiariamente ao processo do trabalho por meio de uma interpretação normativa a partir do conceito de lacuna ontológica (heterointegração).

O uso conjugado dos referidos institutos vai ao encontro da valorização da decisão de primeiro grau, na medida em que permite ao juiz, de plano, entregar ao jurisdicionado a tutela referente ao pedido incontroverso, permitindo o gozo célere de parte de seu direito.

O tempo do processo, caracterizado como um ônus, dentro desta nova dinâmica, passa a ser repartido entre as partes, e aquela que já usufrui de pelo menos parcela de seu direito logo no início da lide tem melhores condições de aguardar o desenvolvimento do processo.

O magistrado de primeira instância, neste contexto, atua de forma mais ativa e é favorecido pelos benefícios decorrentes do contato direto com as partes, podendo agir em prol de uma mudança de cultura na seara laboral e da promoção de direitos fundamentais trabalhistas.

\section{REFERÊNCIAS BIBLIOGRÁFICAS}

ANDRADE, E. Mandado de segurança: a busca da verdadeira especialidade(proposta de releitura à luz da efetividade do processo). Rio de Janeiro: Lumen Juris,2010.

ARAÚJO, J. H. M. Tutela antecipada do pedido incontroverso: estamos preparados para a nova sistemática processual?Revista de Processo, n. 116. jul.-ago. 2004. 
BEDAQUE, J. R. S. Tutela cautelar e tutela antecipada: tutelas sumárias e de urgência (tentativa de sistematização). 3. ed. rev. e ampl. São Paulo:Malheiros, 2003.

BITTAR, E. C. B. O direito na pós-modernidade. Revista Sequência, n. 57, p. 131-152, dez. 2008.

BRASIL. Decreto-Lei n ${ }^{\circ} 5.452$, de $1^{\circ}$ de maio de 1943. Aprova a Consolidação das Leis do Trabalho. Diário Oficial da União, Rio de Janeiro, RJ, 9 ago. 1943. Disponível em: <http://www.planalto.gov.br/ccivil_03/decreto-lei/ del5452.htm>. Acesso em: 15 dez. 2014.

BRASIL. Lei n. 5.869, de 11 de janeiro de 1973. Institui o Código de Processo Civil. Diário Oficial da União, Brasília, DF, 17 jan. 1973. Disponível em: <http://www.planalto.gov.br/ccivil_03/leis/15869.htm>. Acesso em: 15. dez. 2014.

BRASIL. Constituição (1988). Constituição da República Federativa do Brasil. Brasília, DF: Senado, 1988.

BRASIL. Proposta de redação final. Projeto de Lei no 6.025, de 2005. Migalhas. Disponível em: <http://www.migalhas.com.br/arquivos/2014/3/ art20140326-01.pdf>. Acesso em: 19 dez. 2014.

BRASIL. Anteprojeto do novo Código de Processo Civil. Brasília, DF, 2010. Disponível em: <http://www.senado.gov.br/senado/novocpc/pdf/ anteprojeto.pdf $>$.Acesso em: 20 out. 2014. 
BRASIL. Senado Federal. Reforma do Código de Processo Civil. Relatório. 2014. Disponível em: <file:///C:/Users/Aline/Downloads/NCPC_ Senado_27nov14.pdf>. Acesso em: 19 dez. 2014.

BRASIL. Lei no 13.105, de 16 de março de 2015. Código de Processo Civil. Diário Oficial da União, Brasília, DF, 17 mar. 2015. Disponível em: <http:// www.planalto.gov.br/ccivil_03/_Ato2015-2018/2015/Lei/L13105.htm>. Acesso em: 10 mai. 2015.

BUENO, C. S.Tutela antecipada. São Paulo: Saraiva, 2004.

BUENO, C. S.Execução provisória. In: LOPES, J. B.; CUNHA, L. J. C.da (Coords.). Execução civil (aspectos polêmicos). São Paulo: Dialética, 2006.

CHAVES, L. A. A irrecorribilidade das decisões interlocutórias no processo do trabalho e os avanços no direito processual civil. Revista Trabalhista: Direito e Processo, Rio de Janeiro, v. 6, n. 24, p. 87-117, out.-dez., 2007a.

CHAVES, L. A. A recente reforma no processo comum e seusreflexos no direito judiciário do trabalho. 3.ed. rev. e ampl. São Paulo: LTr, 2007b.

DALAZEN, J. O. Aspectos da tutela antecipatória de mérito no processo trabalhista brasileiro. Revista do Tribunal Regional do Trabalho da $3^{\text {a }}$ Região,Belo Horizonte, v.1, n.55-56, p.39-46, jul. 1997.

DORIA, R. D.A tutela antecipada em relação à parte incontroversa dademanda. 2. ed. rev. e atual. de acordo com a Lei no 10.444. São Paulo: Revista dosTribunais, 2004. 
FERREIRA, A. B. H. Novo dicionário Aurélio da língua portuguesa. 4.ed. Curitiba: Positivo, 2009.

FREITAS, N. O. Compreensão da celeridade processual a partir da hermenêutica constitucional. In: CASTRO, J. A. L.(Coord.). Direito processual: estudos no Estado Democrático de Direito. Belo Horizonte: PUC Minas/ Instituto de Educação Continuada, 2008.

GARCIA, G. F. B. Curso de direito processual do trabalho. 6. ed.Rio de Janeiro: Forense, 2012.

GONÇALVES, G. F. M. Direito e tempo.In: JAIME, F. G.; FARIA,J. C.de; LAUAR, M.T. (Orgs.). Processo civil:novas tendências.Homenagem ao ministro Sálvio de Figueiredo Teixeira. BeloHorizonte: Del Rey, 2011.

LEITE, C. H. B. As recentes reformas do CPC e as lacunas ontológicas e axiológicas no processo do trabalho sob a perspectiva da efetividade do acesso à justiça. Revista do Tribunal Superior do Trabalho, Brasília, v. 73, n. 1, p. 98-106, jan.-mar. 2007.

Curso de direito processual do trabalho. 6. ed. São Paulo:

LTr, 2008.

LEITE, C. H. B.; EÇA, V. S. M. Direito material e processual do trabalho na perspectiva dos direitos humanos. São Paulo: LTr, 2014.

MARINONI, L. G.Efetividade do processo e tutela de urgência. Porto Alegre: Fabris, 1994. 
.Tutela antecipatória e julgamento antecipado: parte incontroversa dademanda. 5. ed. rev., atual. eampl. São Paulo: Revista dosTribunais, 2002.

.Antecipação da tutela. 11. ed. rev., atual. eampl. São Paulo: Revista dosTribunais, 2009.

MOURA EÇA, V. S. de.; MAGALHÃES, A. C. Concretização do direito fundamental de acesso à justiça na seara laboral através da tutela da evidência. In: BEZERRA LEITE, C. H.;(Coords.).Direito material e processual do trabalho na perspectiva dos direitos humanos. São Paulo: LTr, 2014.

PIMENTA, J. R. F.Tutelas de urgência no processo do trabalho: o potencial transformador das relações trabalhistas das reformas do CPC brasileiro. In; PIMENTA, L. G.et al., (Coords.). Direito do trabalho: evolução, crise, perspectivas. São Paulo: LTr. 2004.

SCHIAVI, M. Aspectos polêmicos e atuais da teoria geral do processo do trabalho -civitização do direito processual do trabalho ou melhoria da prestação jurisdicionaltrabalhista? Revista Legislação do Trabalho, São Paulo,ano 74, set. 2010.

THEODORO JÚNIOR, H. Curso de direito processual civil. Teoria geral do direito processual civil e processo de conhecimento. 44. ed. Rio deJaneiro: Forense, 2006.v. 1. 
THEODORO JÚNIOR, H. Direitofundamental à duração razoável do processo. 2008. Disponível em: <http://www.anima-opet.com.br/segunda_edicao/Humberto_Theodoro_Junior.pdf >. Acesso em 16 dez. 2014.

WATANABE, K. Da cognição no processo civil. 2.ed. atual. Campinas: Bookseller, 2000.

ZAVASCKI, T. A. Antecipação da tutela. 7. ed. São Paulo: Saraiva, 2009.

Recebido em 02/08/2015 - Aprovado em 11/09/2015. 